\title{
Prevalence and risk factors associated with Ehrlichia infections in smallholder dairy cattle in Nairobi City County, Kenya
}

\author{
Shepelo Getrude Peter ${ }^{1}$, Daniel Waweru Gakuya ${ }^{1}$, Ndichu Maingi² and Charles Matiku Mulei ${ }^{1}$
}

1. Department of Clinical Studies, Faculty of Veterinary Medicine, University of Nairobi, Kenya; 2. Department of Veterinary Pathology, Microbiology and Parasitology, Faculty of Veterinary Medicine, University of Nairobi, Kenya. Corresponding author: Shepelo Getrude Peter, e-mail: shepelo@uonbi.ac.ke

Co-authors: DWG: danielgakuya@yahoo.com, NM: nmaingi@uonbi.ac.ke, CMM: cmulei@uonbi.ac.ke Received: 29-05-2019, Accepted: 03-09-2019, Published online: 24-10-2019

doi: www.doi.org/10.14202/vetworld.2019.1599-1607 How to cite this article: Peter SG, Gakuya DW, Maingi N, Mulei CM (2019) Prevalence and risk factors associated with Ehrlichia infections in smallholder dairy cattle in Nairobi City County, Kenya, Veterinary World, 12(10): 1599-1607.

\begin{abstract}
Background and Aim: Ehrlichiosis caused by Ehrlichia ruminantium is a tick-borne disease of great economic importance in cattle production worldwide. Despite its economic impact, limited knowledge is available on its epidemiology in Africa, including Kenya. Suspected cases of E. ruminantium infections have been reported in the recent past to the University of Nairobi's Veterinary Hospital, prompting the need to investigate their possible re-emergence. Therefore, this study was aimed at determining the prevalence of E. ruminantium among smallholder dairy cattle in Nairobi City County and to assess potential risk factors. This knowledge may guide the development of appropriate control strategies of ehrlichiosis, subsequently reducing associated losses.
\end{abstract}

Materials and Methods: A total of 107 smallholder dairy farms from Nairobi City County were recruited for the study. Blood samples were collected from 314 apparently healthy dairy cattle, and Giemsa-stained blood smears were screened under the microscope for Ehrlichia species. A commercial antigen enzyme-linked immunosorbent assay (ELISA) kit was then used to confirm the presence of the infections in serum samples. A pre-tested questionnaire was used to collect data on management practices that may be potential risk factors. A univariate and mixed-effects logistic regression was then used to determine significant risk factors.

Results: On microscopy, 79.3\% (249/314) of the sampled animals had Ehrlichia-like inclusion bodies in white blood cells, though only $18.6 \%$ (95\% confidence interval [CI] 14.2-23.0) of these were confirmed to be E. ruminantium on ELISA. A farm-level prevalence of 35.5\% (95\% CI 27.0-45.3) was reported. Female-headed households ( $p=0.013)$, farms in Langata region $(\mathrm{p}=0.027)$, cleaning of cowsheds fortnightly $(\mathrm{p}=0.019)$, and roofing of cowshed $(\mathrm{p}=0.022)$ were factors significantly associated with E. ruminantium infections.

Conclusion: There is a relatively high prevalence of $E$. ruminantium infections in apparently healthy cattle in smallholder dairy farms in this area, warranting control measures. It is critical to improve animal welfare-related factors, such as cowshed cleaning and roofing, as well as the strategic location of farms, especially, since reservoirs may reduce infection levels in the farms, in relation to wildlife. However, since Ehrlichia-like inclusion bodies other than those of E. ruminantium were observed in this study, there is a need to investigate further these factors and the possibility of other Ehrlichia species infecting cattle in the study area.

Keywords: Ehrlichia ruminantium, enzyme-linked immunosorbent assay, inclusion bodies, microscopy, tick-borne disease.

\section{Introduction}

Ehrlichiosis is a broad term referring to tick-borne diseases (TBDs) of multiple animal species caused by obligate intracellular organisms of the white blood cells [1]. Ehrlichia ruminantium is the main Ehrlichia species infecting cattle in Africa and the Caribbean Islands [2]. It is transmitted by infected ticks in the genus Amblyomma [2,3]. Despite E. ruminantium being among the most important TBD affecting millions of cattle in sub-Saharan Africa and being an OIE listed disease [4-7], there is limited information on its epidemiology in

Copyright: Peter, et al. Open Access. This article is distributed under the terms of the Creative Commons Attribution 4.0 International License (http://creativecommons.org/licenses/by/4.0/), which permits unrestricted use, distribution, and reproduction in any medium, provided you give appropriate credit to the original author(s) and the source, provide a link to the Creative Commons license, and indicate if changes were made. The Creative Commons Public Domain Dedication waiver (http://creativecommons.org/ publicdomain/zero/1.0/) applies to the data made available in this article, unless otherwise stated.
Africa, including Kenya [8]. Instead, other TBDs, such as East Coast Fever, anaplasmosis, and babesiosis, have been considered the most important for cattle throughout Eastern Africa, including Kenya $[9,10]$. This may be a consequence of certain reports of the low prevalence of E. ruminantium in some parts of Africa and even Kenya, including $0.6 \%$ in Ethiopia [11], 0.4\% in Kenya [12], and $1.1 \%$ and $1.7 \%$ in Nigeria and Uganda, respectively $[13,14]$. Due to the high demand for milk, market forces and the convenience of urban areas, there has been a constant rise in dairy cattle keeping in urban areas of Kenya [15]. These smallholder dairy production systems in urban and peri-urban areas experience unique challenges where their substandard animal husbandry practices compromise animal welfare, thereby predisposing the cattle to stressful conditions and, as a result, various diseases [16].

TBDs are the most important diseases affecting these smallholder dairy farms, mainly due to dynamic 
tick vectors, increasing the susceptibility of the exotic breeds kept in the farms [17]. E. ruminantium infections cause severe economic losses in Africa, where approximately 150 million animals are at risk of infection [7], thereby negatively affecting livelihoods that depend on cattle. The estimation of these losses in endemic areas is complicated by the fact that farmers do not provide regular reports, definitive diagnoses are hardly delivered [7], and infections often coincide with other TBDs such as anaplasmosis and East Coast Fever [2]. Despite this, the few economic studies that have been carried out have pointed to quite substantial economic losses. In Zimbabwe, losses of USD 5.6 million/year have been reported, with acaricide costs accounting for $76 \%$ and milk losses accounting for $18 \%$ of the total cost [18]. In a 3-year follow-up study in Ethiopia, losses from mortalities, cost of acaricides and antibiotics, and losses in milk and meat have resulted in total costs of USD 7884.67 million [8]. In Tanzania, economic losses of USD 22.6 million/year have been recorded, with cattle mortality accounting for 8.8 million USD [19].

Suspected cases of ehrlichiosis have been reported since 2014 at the University of Nairobi Veterinary Hospital, which mainly serves Nairobi City County and its peri-urban areas. These cases present with non-specific clinical signs such as inappetence, unthriftiness and, at times, death. When they are screened by a blood smear microscopy, Ehrlichialike inclusion bodies have been shown in the white blood cells of affected animals. The difficulty in diagnosing $E$. ruminantium infections due to their non-pathognomonic clinical signs has been emphasized by Allsopp and has resulted in the underestimation of economic losses, especially in endemic areas including Kenya [2].

This study was therefore aimed at determining whether the inclusion bodies observed in blood samples collected from smallholder dairy farms within Nairobi City County were those of E. ruminantium, and to assess potential risk factors, therefore warranting the development of appropriate control measures in these farms.

\section{Materials and Methods}

\section{Ethical approval}

The study was approved by Biosecurity, Animal Use and Ethics Committee, Faculty of Veterinary Medicine, University of Nairobi (FVM BAUEC/2016/122). Experiments were carried out in accordance with the guidelines laid down by the International Animal Ethics Committee or Institutional Ethics Committee and in accordance with local laws and regulations.

\section{Informed consent}

The study was discussed with owners of the animals who were to be recruited and thereafter they signed written consent. They were free to make the decision to join the study or withdraw.

\section{Study area and study population}

The study was conducted in Nairobi City County's Nairobi City, which is the capital city of Kenya and is located at 1.28333 latitude and 36.81667 longitude and $1795 \mathrm{~m}$ above sea level. The county has 17 sub-counties, the highest number of administrative units in a single county in Kenya. The city has a population of slightly over 3 million people. In the peri-urban areas of the city, there are the smallholder dairy production systems established to meet the high demand for the milk of the city. The previously reported incidence of TBD in these peri-urban areas of Nairobi was $7.8 \%$ [10].

\section{Study design}

Nairobi City County was divided into four quadrants centered around the city's central business district (Figure-1). In each of the quadrants, purposive sampling was used to identify the sub-county with the highest cattle population, which was included in the study. The sub-counties identified in each quadrant were Dagoretti, Langata, Ruai, and Westlands. Transect walks were then used to identify smallholder dairy farms in the sub-counties. Smallholder dairy farms were described as those with between 2 and 10 dairy cattle [20]. In each transect the tenth; dairy unit was included in the study depending on the owner's willingness to participate. Otherwise, if they refused to give consent, the next dairy unit was recruited. Animals were grouped into age groups (calves $<12$ months, yearlings $12-\leq 24$ months, and adults $>24$ months). A maximum of two animals in each age group was included in the study. Where there were more than two animals in a specified age group, two were randomly selected. A pre-tested questionnaire was administered to the principal farmer or stockman who spent the most time with the cattle to collect farm-level management factors that were thought to be associated with Ehrlichia infections. Using an expected prevalence of E. ruminantium of $4.5 \%$ [21] and sample size calculation formulae according to Charan and Biswas [22], the minimum target sample size was found to be 66 cattle.

\section{Data and sample collection}

Data on the various farm-level factors, especially management practices (feeding system, source of fodder, cowshed cleaning, tick control, nature of housing, and introduction of new animal) and animal level factors (age, sex, breed, and lactation status) were collected using the pre-tested questionnaire. Blood was collected from the coccygeal vein and put in vacutainers with clot activator and allowed to stand for $2 \mathrm{~h}$. The serum was then decanted in a labeled Eppendorf tube and centrifuged for $10 \mathrm{~min}$ at $3000 \times \mathrm{g}$, then decanted into the final Eppendorf tube and stored at $-20^{\circ} \mathrm{C}$ until further analysis. Ablood smear was immediately prepared at the farm, fixed using absolute ethanol, and later Giemsa-stained.

\section{Laboratory analysis}

Microscopy was done using a light microscope at $1000 \times$ oil emersion on the Giemsa-stained 


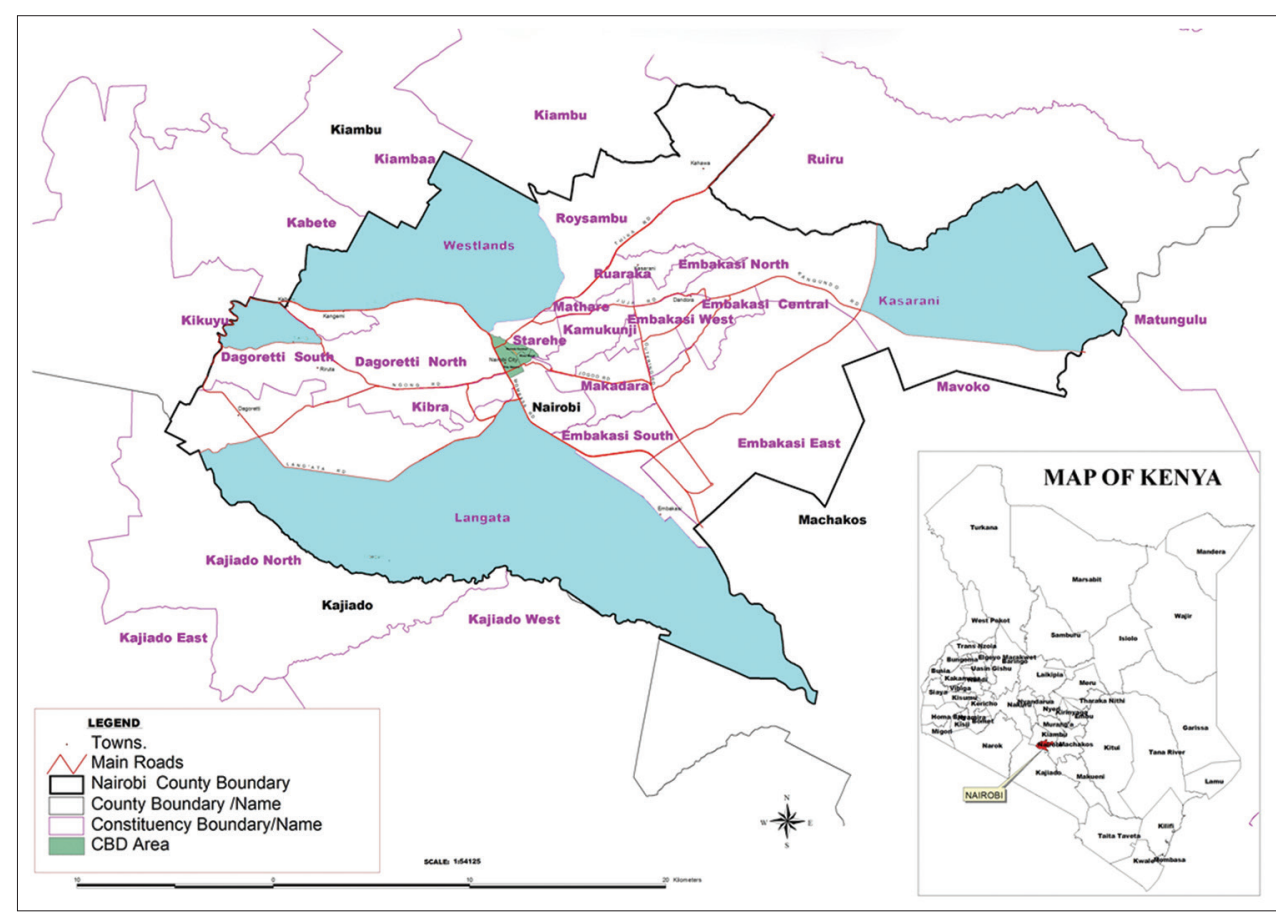

Figure-1: Map of Nairobi City County highlighting the sub-counties that were sampled.

[Source: Independent Electoral and Boundaries Commission, Kenya https://www.iebc.or.ke/uploads/resources/WHXao7x83D.pdf]

smears where the white blood cells (neutrophils, lymphocytes, and monocytes) were assessed for any cytoplasmic inclusion bodies. Antigen enzyme-linked immunosorbent assay (ELISA) for E. ruminantium was done on the harvested serum using commercial kits BIOS microwell ELISA diagnostic systems, USA, following the manufacturer's instructions.

\section{Statistical analysis}

Questionnaire data were input into Excel 2016 before it was exported to Stata 15.0 for analysis. Descriptive statistics expressed as proportions were computed for the farm and animal level factors in the study area. Univariate logistic regression was used to test for associations between the various possible risk factors as explanatory variables and E. ruminantium-positive outcome on ELISA. Factors with $\mathrm{p} \leq 10 \%$ were analyzed using mixed-effects logistic regression model followed by step-wise elimination such that only factors with $p<5 \%$ were left in the final model and were identified as being statistically associated with $E$. ruminantium infections.

\section{Results}

\section{Microscopic examination}

A total of 314 blood samples were collected from cattle in 107 smallholder dairy farms from the four selected regions in Nairobi City County. Inclusion bodies were observed in white blood cells in $79.3 \%$ (249/314) (95\% confidence interval [CI] 74.4-83.6) of the samples examined. The Dagoretti region had the highest number of animals, with inclusion bodies in their white blood cells, totaling 89.5 (94/105). The Westlands and Ruai regions reported the lowest
Table-1: Distribution of number and percentage of Ehrlichia-like inclusion bodies in four different regions in Nairobi City County, Kenya.

\begin{tabular}{lcc}
\hline Region & $\begin{array}{c}\text { Number of } \\
\text { samples }\end{array}$ & $\begin{array}{c}\text { Ehrlichia-like inclusion } \\
\text { bodies present (\%) }\end{array}$ \\
\hline Dagoretti region & 105 & $94(89.5)$ \\
Langata region & 60 & $50(83.3)$ \\
Ruai region & 102 & $72(70.6)$ \\
Westlands region & 47 & $33(70.2)$ \\
Total & 314 & $249(100)$ \\
\hline
\end{tabular}

numbers of animals with inclusion bodies among the animals examined (Table-1).

Out of the 249 samples that were positive on microscopic analysis, 145 samples that had clean blood smears were scrutinized to assess the specific white blood cells that had Ehrlichia-like inclusion bodies. Of all the cells that were examined, $49.7 \%(72 / 145)$ had Ehrlichia-like inclusion bodies in monocytic cells, while only $4.8 \%(7 / 145)$ were in granulocytic cells. The other $45.5 \%(66 / 145)$ of the samples had inclusion bodies in both granulocytic and monocytic cells. Among the monocytic cells, the lymphocytes were most commonly affected, representing $37.2 \%$ of the cells $(54 / 145)$ followed by monocytes, representing $12.4 \%(18 / 145)$ of the cells. Figure-2 shows the Ehrlichia-like inclusion bodies as they appear in different white blood cells.

Determination of $E$. ruminantium infections in smallholder dairy farms in Nairobi City County using ELISA

Antigen ELISAs were carried to confirm whether the Ehrlichia-like inclusion bodies were those of E. ruminantium or not. The ELISA was done on 296 of the samples that were examined by microscopy, of which $18.6 \%(55 / 296)(95 \%$ CI [14.2-23.0]) 
were positive for $E$. ruminantium. Of all the sampled farms, nearly a third of them, representing $35.5 \%$ (38/107) (95\% CI [27.0-45.3]), had animals positive for E. ruminantium.

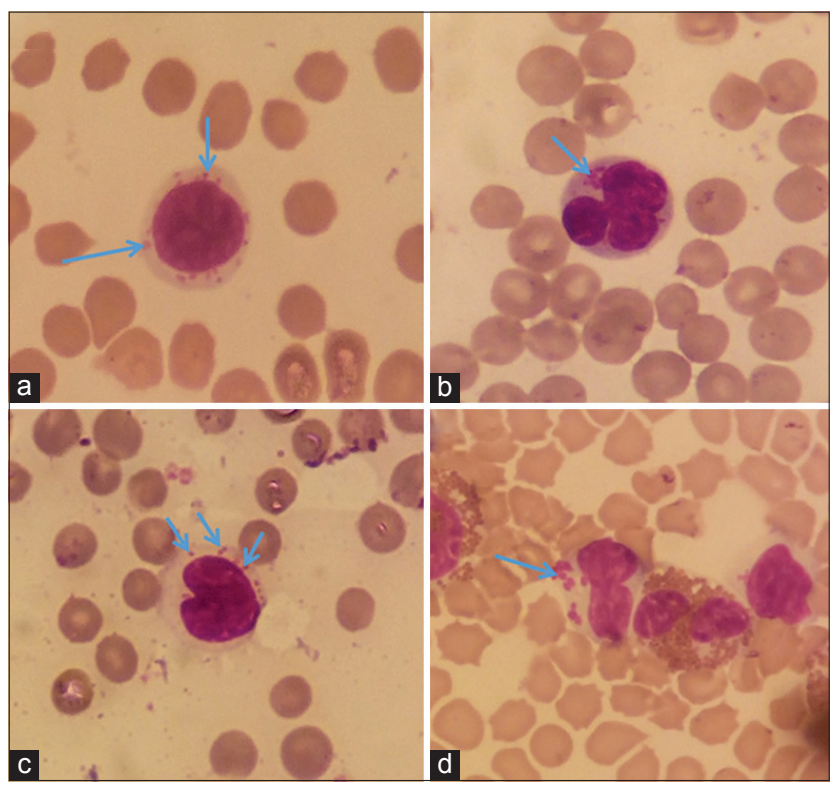

Figure-2: Ehrlichia-like inclusion bodies (blue arrows) as observed under a light microscope $(1000 \times)$ oil immersion in a lymphocyte (a), neutrophil (b), and a monocyte (c and d).
Description of factors associated with E. ruminantium infections in smallholder dairy farms in Nairobi City County

Table-2 describes the distribution of the various factors among the study's farms. Ehrlichia positive farms were more prevalent in female-headed households, representing $60 \%(23 / 38)$, than in male-headed households, representing $39.5 \%(15 / 38)$ of the farms. The majority of the positive farms were in the Ruai region $42.1 \%(16 / 38)$, although fewer farms were sampled from the Westlands and Langata Regions. There were more farms with E. ruminantium infections in which employees had only attained a primary education or lower, representing $44.8 \%$ (17/38) of the farms, in comparison to farms in which employees had attained a higher educational level, representing $15.8 \%$ $(6 / 38)$ of the farms. There were more E. ruminantium infections, representing $57.8 \%(22 / 38)$, in farms where the owners had additional sources of income from businesses, compared to farms in which the owners depended solely on livestock or their salary, representing $23.7 \%$ (9/38) of farms.

Stall feeding was the main method of feeding the dairy cattle, and the majority of the infected farms, representing $76.3 \%$ (29/39), were in this category. E. ruminantium infections were lower in farms in which fodder fed to the animals was sourced from

Table-2: Description of farm and animal level factors associated with Ehrlichia ruminantium infections among 296 dairy cattle in 107 smallholder dairy farms across Nairobi City County.

\begin{tabular}{|c|c|c|}
\hline Parameter & Description & Ehrlichia ruminantium positive (\%) \\
\hline \multicolumn{3}{|l|}{ Farm-level factors } \\
\hline \multirow[t]{2}{*}{ Gender of household head } & Female-headed household $(n=42)$ & $23(60.0)$ \\
\hline & Male-headed household $(n=65)$ & $15(39.5)$ \\
\hline \multirow[t]{4}{*}{ Region } & Dagoretti region $(n=52)$ & $12(31.6)$ \\
\hline & Ruai region $(n=39)$ & $16(42.1)$ \\
\hline & Westlands region $(n=7)$ & $4(10.5)$ \\
\hline & Langata region $(n=9)$ & $6(15.8)$ \\
\hline \multirow[t]{2}{*}{ Employee present } & Yes $(n=67)$ & $24(63.2)$ \\
\hline & No $(n=38)$ & $14(36.8)$ \\
\hline \multirow[t]{3}{*}{ Employee's education level } & $\begin{array}{l}\text { Employees' highest level of education was } \\
\text { primary }(n=42)\end{array}$ & $17(44.8)$ \\
\hline & $\begin{array}{l}\text { Employees' highest level of education was } \\
\text { secondary }(n=23)\end{array}$ & $6(15.8)$ \\
\hline & $\begin{array}{l}\text { Employees' highest level of education was } \\
\text { tertiary }(n=4)\end{array}$ & $1(2.6)$ \\
\hline \multirow[t]{3}{*}{ Farmer's education level } & $\begin{array}{l}\text { Owners' highest level of education was } \\
\text { primary }(n=27)\end{array}$ & $11(28.9)$ \\
\hline & $\begin{array}{l}\text { Owners' highest level of education was } \\
\text { secondary }(n=42)\end{array}$ & $12(31.6)$ \\
\hline & $\begin{array}{l}\text { Owners' highest level of education was } \\
\text { tertiary }(n=38)\end{array}$ & $15(39.5)$ \\
\hline \multirow[t]{2}{*}{ Farming system } & $\begin{array}{l}\text { Farming system involved livestock } \\
\text { only }(n=7)\end{array}$ & $6(15.8)$ \\
\hline & $\begin{array}{l}\text { Farming system involved livestock and } \\
\text { crops }(n=100)\end{array}$ & $32(84.2)$ \\
\hline \multirow[t]{3}{*}{ Other sources of income } & No other source of income $(n=34)$ & $9(23.6)$ \\
\hline & Additional income from salary $(n=20)$ & $7(18.4)$ \\
\hline & Additional income from business $(n=53)$ & $22(57.8)$ \\
\hline \multirow[t]{3}{*}{ Feeding system } & Stall feeding only $(n=86)$ & $29(76.3)$ \\
\hline & Free grazing only $(n=3)$ & $2(5.3)$ \\
\hline & Stall feeding and free grazing $(n=18)$ & $7(18.4)$ \\
\hline
\end{tabular}


Table-2: (Continued)

\begin{tabular}{|c|c|c|}
\hline Parameter & Description & Ehrlichia ruminantium positive (\%) \\
\hline \multirow[t]{3}{*}{ Source of fodder } & Fodder sourced from own farm $(n=38)$ & $10(26.3)$ \\
\hline & $\begin{array}{l}\text { Fodder sourced from own farm and } \\
\text { purchase }(n=32)\end{array}$ & $15(39.5)$ \\
\hline & $\begin{array}{l}\text { Fodder is purchased and cut from roadside } \\
\text { grazing }(n=37)\end{array}$ & $13(34.2)$ \\
\hline \multirow[t]{2}{*}{ Hay feeding } & Fed on hay $(n=90)$ & $33(86.8)$ \\
\hline & Not fed on hay $(n=17)$ & $5(13.2)$ \\
\hline \multirow[t]{2}{*}{ Fencing of pastureland } & Pastureland fenced $(n=89)$ & $32(84.2)$ \\
\hline & Pastureland not fenced $(n=18)$ & $6(15.8)$ \\
\hline \multirow[t]{3}{*}{ Cleaning of cowshed } & Cowshed cleaned daily $(n=78)$ & $23(60.5)$ \\
\hline & Cowshed cleaned every other day $(n=10)$ & $3(7.9)$ \\
\hline & Cowshed cleaned fortnightly $(n=19)$ & $12(31.6)$ \\
\hline \multirow[t]{3}{*}{ Type of cowshed floor } & Earthen cowshed floor $(n=19)$ & $10(26.3)$ \\
\hline & Cemented cowshed floor $(n=60)$ & $19(50.0)$ \\
\hline & Cowshed floor has stones $(n=28)$ & $9(23.7)$ \\
\hline \multirow[t]{2}{*}{ Presence of cowshed bedding } & Bedding present on cowshed floor $(n=52)$ & $18(47.4)$ \\
\hline & Bedding absence on cowshed floor $(n=55)$ & $20(52.6)$ \\
\hline \multirow[t]{2}{*}{ Presence of cowshed roof } & Roof present on cowshed $(n=100)$ & $34(89.5)$ \\
\hline & Roof absent on cowshed $(n=7)$ & $4(10.5)$ \\
\hline \multirow[t]{2}{*}{ Tick control on cattle } & Practicing tick control $(n=79)$ & $29(76.3)$ \\
\hline & Not practicing tick control $(n=28)$ & $9(23.7)$ \\
\hline \multirow[t]{3}{*}{ Frequency of tick control } & Acaricide applied weekly $(n=47)$ & $17(44.7)$ \\
\hline & Acaricide applied monthly $(n=40)$ & $19(50.0)$ \\
\hline & Acaricide applied every 3 months $(n=20)$ & $2(5.3)$ \\
\hline \multirow[t]{3}{*}{ Method of acaricide application } & Hand spray $(n=96)$ & $31(81.6)$ \\
\hline & Pour on $(n=8)$ & $5(13.2)$ \\
\hline & Other methods $(n=3)$ & $2(5.3)$ \\
\hline \multirow{2}{*}{$\begin{array}{l}\text { Presence of new animal in the } \\
\text { herd }\end{array}$} & Introduction of new animals $(n=31)$ & $12(31.2)$ \\
\hline & $\begin{array}{l}\text { Farms with no new animals } \\
\text { introduced }(n=76)\end{array}$ & $26(68.4)$ \\
\hline \multicolumn{3}{|l|}{ Animal-level Factors } \\
\hline \multirow{3}{*}{ Age of the animal } & Calves $(n=80)$ & $13(4.4)$ \\
\hline & Yearlings $(n=73)$ & $12(4.1)$ \\
\hline & Adults $(n=143)$ & $30(10.1)$ \\
\hline \multirow[t]{5}{*}{ Animal breed } & Friesian $(n=183)$ & $27(9.1)$ \\
\hline & Guernsey $(n=10)$ & $2(0.7)$ \\
\hline & Ayrshire $(n=55)$ & $4(1.4)$ \\
\hline & Indigenous $(n=39)$ & $22(7.4)$ \\
\hline & Jersey $(n=9)$ & $0(0)$ \\
\hline \multirow[t]{2}{*}{ Sex of the animal } & Female $(n=268)$ & $46(15.5)$ \\
\hline & Male $(n=28)$ & $9(3.0)$ \\
\hline \multirow[t]{3}{*}{ Lactational status } & Lactating $(n=122)$ & $22(74.3)$ \\
\hline & Pregnant $(n=11)$ & $3(1.0)$ \\
\hline & Calves/heifers/male $(n=163)$ & $30(10.1)$ \\
\hline
\end{tabular}

their own farm, representing $26.3 \%$ (10/38) of farms, in comparison to farms in which the fodder was purchased. In addition, farms that supplemented the fodder with hay feeding had high infection rates, of $86.8 \%(33 / 38)$, compared to those that did not feed hay $13.2 \%(5 / 38)$. Infection rates were also high in farms in which the cowshed was cleaned on a daily basis, representing $60.5 \%(23 / 38)$ of farms, and the cowshed floor was cemented, representing 50\% (19/38) of the farms. Tick control was a major practice in the majority of the study farms, representing $73.8 \%(79 / 107)$ of the farms, though E. ruminantium infections remained high, affecting $76.3 \%(29 / 38)$ of farms, especially in farms implementing hand spraying $81.6 \%(31 / 38)$.

The majority of animals sampled were adults, representing 48.3\% (143/296), and accounted for the highest age group with $E$. ruminantium infections, representing $10.1 \%(30 / 296)$. The main breed kept in the study farms was Friesian 61.8\% (183/296), and, being dairy farms, the majority of animals were females $90.5 \%$ (268/296).

Analysis of risk factors associated with E. ruminan-
tium infections among 296 dairy cattle across 107
smallholder dairy farms in Nairobi City County

On univariate analysis, factors found to be statistically significant, at $p \leq 0.1$, were the gender of household head, region, farming systems, cleaning of cowshed, type of cowshed floor, presence of cowshed roof, and breed of the animal (Table-3). A mixed-effects logistic regression analysis revealed that the factors significantly associated with seropositivity were farms in which the household head was female $(p=0.013)$, farms from the Langata region $(p=0.027)$, cleaning of the cowshed every fortnight $(p=0.019)$, and farms in which the cowsheds had roofs $(p=0.022)($ Table-4). Farms in which the household head was female were 2.4 times more likely to have $E$. 
Table-3: Univariate logistic regression of factors associated with Ehrlichia ruminantium among 296 dairy cattle across 107 smallholder farms in Nairobi City County.

\begin{tabular}{|c|c|c|c|c|}
\hline \multirow[t]{2}{*}{ Parameter } & \multirow[t]{2}{*}{ Estimate } & \multirow[t]{2}{*}{ p-value } & \multicolumn{2}{|c|}{$95 \%$ Confidence interval } \\
\hline & & & Lower & Upper \\
\hline Gender of household head & -1.356 & $0.003^{*}$ & -2.194 & -0.514 \\
\hline Region & 0.263 & $0.099 *$ & -0.049 & 0.5745 \\
\hline Gender of owner & 0.117 & 0.671 & 0.655 & 0.421 \\
\hline Employee present & -0.336 & 0.471 & -1.250 & 0.578 \\
\hline Farmer's education level & -0.204 & 0.454 & -0.738 & 0.330 \\
\hline Farming system & -0.204 & $0.005^{*}$ & -2.948 & -0.526 \\
\hline Other sources of income & 0.067 & 0.795 & -0.438 & 0.572 \\
\hline Duration of farming & 0.016 & 0.995 & -0.031 & 0.031 \\
\hline Feeding system & -0.019 & 0.950 & -0.571 & 0.536 \\
\hline Source of fodder & 0.266 & 0.901 & -0.553 & 0.488 \\
\hline Feeding of hay & -0.057 & 0.929 & -1.314 & 1.200 \\
\hline Area for fodder growing & -0.133 & 0.258 & -0.363 & 0.097 \\
\hline Fencing of pastureland & -0.158 & 0.773 & -1.230 & 0.915 \\
\hline Cleaning of cowshed & 0.989 & $<0.001 *$ & 0.514 & 1.464 \\
\hline Type of cowshed floor & -0.839 & $0.006 *$ & -1.437 & -0.241 \\
\hline Presence of cowshed bedding & -0.371 & 0.389 & -1.215 & 0.473 \\
\hline Presence of cowshed roof & -2.551 & $<0.001 *$ & -3.720 & -1.382 \\
\hline Tick control on cattle & 0.309 & 0.559 & -0.727 & 1.344 \\
\hline Frequency of tick control & -0.108 & 0.781 & -0.866 & 0.651 \\
\hline Method of acaricide application & 0.643 & 0.279 & -0.521 & 1.807 \\
\hline New animals in the herd & 0.008 & 0.986 & -0.919 & 0.936 \\
\hline Age of the animal & 0.171 & 0.423 & -0.248 & 0.590 \\
\hline Breed of the animal & 0.263 & $0.062 *$ & -0.013 & 0.540 \\
\hline Sex of the animal & -0.668 & 0.212 & -1.717 & 0.380 \\
\hline Lactation status & -0.023 & 0.898 & -0.380 & 0.333 \\
\hline Parity & -0.064 & 0.491 & -0.248 & 0.119 \\
\hline
\end{tabular}

*Factors statistically significant at $\mathrm{p} \leq 0.1$

Table-4: Mixed effects logistic regression analysis of the factors significantly associated with Ehrlichia ruminantium among 296 dairy cattle across 107 smallholder farms in Nairobi City County.

\begin{tabular}{|c|c|c|c|c|}
\hline \multirow[t]{2}{*}{ Parameter } & \multirow[t]{2}{*}{ OR } & \multicolumn{2}{|c|}{ 95\% Confidence interval } & \multirow[t]{2}{*}{ p-value } \\
\hline & & Lower & Upper & \\
\hline Female household head & 2.4 & 1.2 & 5.3 & 0.013 \\
\hline Ruai region & 1.0 & 0.4 & 2.6 & 0.950 \\
\hline Westlands region & 2.2 & 0.6 & 8.2 & 0.221 \\
\hline Langata region & 2.9 & 1.1 & 7.6 & $* 0.027$ \\
\hline Dagoretti region & 1 & & & \\
\hline Every other day cleaning of cow shed & 2.5 & 0.6 & 11.2 & 0.216 \\
\hline Cleaning of cow shed fortnightly & 3.6 & 1.2 & 10.7 & $* 0.019$ \\
\hline Daily cleaning of cow shed & 1 & & & \\
\hline Cowshed without a roof & 4.7 & 1.2 & 17.4 & $* 0.022$ \\
\hline Cowshed with a roof & 1 & & & \\
\hline
\end{tabular}

*Factors statistically significant at $\mathrm{p} \leq 0.05$. OR=Odds ratio

ruminantium infections than male-headed households. Farms in the Langata Regions were 2.9 times more likely to be infected with E. ruminantium than farms in the Dagoretti region, while farms that cleaned their cowsheds fortnightly were 3.6 times more likely to be infected with E. ruminantium that those that cleaned their cowsheds on a daily basis. Farms in which cowsheds had no roofs were 4.7 times more likely to be infected by E. ruminantium than those which had cowshed roofs.

\section{Discussion}

In this study, Ehrlichia-like inclusion bodies were observed in the cytoplasm of various white blood cells. Although microscopic examination of endothelial cells from the brain is the common method of diagnosing E. ruminantium, the inclusion bodies of the parasite can still be observed in the neutrophils on stained blood smears [1,23]. In this study, inclusion bodies were also observed in neutrophils as well as in other white cells such as lymphocytes and monocytes. Some of the samples that revealed inclusion bodies on microscopy were negative on ELISA, possibly indicating the presence of other species of Ehrlichia in the cattle since they all parasitize white blood cells [24]. Despite microscopy being cheap and easily available, the low sensitivity and occasional misdiagnosis due to the presence of artifacts in the smears greatly limit 
its use [25]. These limitations may explain the high number of Ehrlichia-like inclusion bodies observed in this study.

The current study used antigen ELISA to detect E. ruminantium in an attempt to overcome the limitations linked to cross-reactivity with other Ehrlichia species [26]. E. ruminantium was detected in apparently healthy cattle, an observation similar to that of Matos et al. [27] but inconsistent with Kelly et al. [28], who points out that E. ruminantium always presents with clinical disease. This may suggest that non-pathogenic strains of the parasite may be in circulation, or those carrier animals have the parasites, thereby posing a threat to susceptible animals [2].

The overall prevalence of E. ruminantium in cattle reported in this study was $18.6 \%$, similar to the $15 \%$ reported in Mozambique [27], though lower than $50 \%$ reported by Swai et al. [29] in Tanzania and $33 \%$ in Zimbabwe [26] and higher than $4.5 \%$ in Uganda [21] and 4.1\% in Ethiopia [25]. This wide variability may suggest differences in factors related to cattle management across various areas. The prevalence recorded in the present study is sufficiently high; however, to warrant the implementation of appropriate control strategies since there may be a risk of clinical disease if susceptible animals are present [29]. The herd prevalence was $35.5 \%$, at nearly twice the animal prevalence, possibly indicating that E. ruminantium infection in this area represents a herd health concern rather than an individual animal's problem [29].

Management practices such as acaricide application and frequency of dipping had previously been reported to be risk factors for E. ruminantium [29,30]. However, these factors were not found to be significant risk factors in the current study. Despite the farmers using acaricide for tick control, therefore ehrlichiosis, its mishandled such as through wrong dilution and application procedures may have led to possible development of ticks' resistance [2,5]. In addition, most of the farms outsourced hay to feed their dairy cattle mainly because they own small land sizes, therefore inadequate fodder for the animals, a common feature of smallholder dairy production units in urban and peri-urban areas in Kenya [16]. The ticks can be carried from the grasses to the stall-fed animals, leading to possible infections.

Farms that cleaned the cowshed fortnightly had increased odds of E. ruminantium infections than those that cleaned them daily. Infrequent removal of slurry from cowsheds has been shown to compromise animal welfare in smallholder dairy units, especially because the housing designs are usually poor, thereby forcing the animals to lie on the slurry for long hours at a time [16]. Poor animal welfare, on the other hand, increases the stress of the affected animals, greatly compromising their immunity and predisposing them to other diseases [31]. This may explain the high number of infected animals in this study. Roofing is part of animal housing that provides protection from extreme weather [32]. Therefore, without roofs in the cowsheds, stressors such as excess cold or heat compromise animals' immunity, possibly explaining the increased rate of E. ruminantium infections in farms with cowsheds without roofs [33].

The farms from the Langata region were more likely to have animals infected with $E$. ruminantium compared to other regions, possibly because this region borders Nairobi National Park and its wild animals, such as the African buffalo, black wildebeest, and eland, since they have been known to be reservoirs of ehrlichiosis, are associated with increased risk of infection [34].

Farms in which the household head is female were more likely to have animals infected with E. ruminantium than those in which the household head is male. These findings are similar to those of Sungirai et al. [5] who noted that women are less educated in the management of dairy enterprises, thereby increasing their risk of disease. Moreover, Tola et al. [35] also noted that women undertake the majority of the labor in dairy enterprises, minimizing their time for decision making, such as with regards to disease management.

A limitation of the current study was that sub-counties were not randomly selected since this is an urban-set up; therefore, dairy farms were only concentrated in certain sub-counties. However, the farms included in the study were well representative of Kenyan urban smallholder dairy farms; keeping 2-10 animals and practicing sub-optimal animal husbandry as described by Nguhiu-Mwangi et al. [16].

\section{Conclusion}

There is a relatively high prevalence of E. ruminantium, both at the animal level (18.6\%) and at the herd-level $(35.5 \%)$, in smallholder dairy production systems in the study region, warranting control measures to be put in place. Farm-level factors that predispose to E. ruminantium infections were identified as infrequent cowshed cleaning, lack of roofing, regions in close proximity to wildlife and female household heads. Moreover, there is a need to further characterize the current strains of $E$. ruminantium in circulation among dairy cattle in this area, especially to determine their virulence since, as reported elsewhere; some may have the zoonotic potential [36]. Increasing the frequency of cowshed cleaning to remove the slurry and roofing cowsheds will greatly improve animal welfare, subsequently boosting their immunity and controlling E. ruminantium infections.

\section{Authors' Contributions}

SGP collected, analyzed the samples, and wrote the manuscript. DWG collected samples and interpreted the data. NM and CMM analyzed and interpreted the data. All the authors read and approved the final manuscript. 


\section{Acknowledgments}

The authors wish to acknowledge the support from the Department of Clinical Studies, Faculty of Veterinary Medicine, University of Nairobi, through the provision of ELISA kits for the serology in this work. Moreover, they greatly appreciate the technical support of Alice Kinyua, Jane Kamau, and Nixon in the hematology and biochemistry laboratories. The authors did not receive any funding for this study. The authors would also like to thank Editage (www.editage. com) for English language editing.

\section{Competing interests}

The authors declare that they have no competing interests.

\section{Publisher's Note}

Veterinary World remains neutral with regard to jurisdictional claims in published map and institutional affiliation.

\section{References}

1. The Center for Food Security and Public Health ISU. (2013) Ehrlichiosis and Anaplasmosis : Zoonotic Species Ehrlichiosis and Anaplasmosis. Available from: http:// www.cfsph.iastate.edu/Factsheets/pdfs/ehrlichiosis.pdf. Last accessed on 14-02-2019.

2. Allsopp, B.A. (2015) Heartwater--Ehrlichia ruminantium infection. Rev. Sci. Tech., 34(2): 557-568.

3. Suliman, S.M. (2011) Molecular Epidemiology of Heartwater (Ehrlichia Ruminantium Infection) in Domestic Ruminants in Sudan. Ph.D. Thesis, University of Khartoum.

4. OIE. (2018) OIE-listed Diseases 2018. OIE - World Organisation for Animal Health. Final Report.

5. Sungirai, M., Moyo, D.Z., De Clercq P. and Madder, M. (2016) Communal farmers' perceptions of tick-borne diseases affecting cattle and investigation of tick control methods practiced in Zimbabwe. Ticks Tick Borne Dis., 7(1): 1-9.

6. Atif, F.A. (2015) Anaplasma marginale and Anaplasma phagocytophilum: Rickettsiales pathogens of veterinary and public health significance. Parasitol. Res., 114(11): 3941-3957.

7. Allsopp, B.A. (2010) Natural history of Ehrlichia ruminantium. Vet. Parasitol., 167(2-4): 123-135.

8. Melaku, A., Basaznew, B., Mersha, C., Wassie, M. and Gizat, A. (2014) A three-year follow-up study on the occurrence of bovine ehrlichiosis (cowdriosis) at Gondar university dairy farm. J. Vet. Med. Anim. Health, 6(3): 83-90.

9. Byaruhanga, C., Collins, N.E., Knobel, D., Kabasa, W. and Oosthuizen, M.C. (2015) Endemic status of tick-borne infections and tick species diversity among transhumant zebu cattle in Karamoja region, Uganda: Support for control approaches. Vet. Parasitol. Reg. Stud. Rep., 1-2: 21-30

10. Gakuya, D.W. and Mulei, C.M. (2005) An investigation of the incidences of east coast fever (ECF), anaplasmosis and babesiosis in the bovine cases managed by ambulatory services of the faculty of veterinary medicine, Kabete. Kenya Vet., 29: 21-24.

11. Teshale, S., Geysen, D., Ameni, G., Dorny, P. and Berkvens, D. (2018) Survey of Anaplasma phagocytophilum and Anaplasma spp. 'Omatjenne' infection in cattle in Africa with special reference to Ethiopia. Parasit. Vectors, 11(1): 162.

12. Njiiri, N.E., Bronsvoort, B.M., Collins, N.E., Steyn, H.C., Troskie, M., Vorster, I., Thumbi, S.M., Sibeko, K.P., Jennings, A., van Wyk, I.C., Mbole-Kariuki, M., Kiara, H., Poole, E.J., Hanotte, O., Coetzer, K., Oosthuizen, M.C., Woolhouse, M. and Toye, P. (2015) The epidemiology of tick-borne hemoparasites as determined by the reverse line blot hybridization assay in an intensively studied cohort of calves in western Kenya. Vet. Parasitol., 210(1-2): 69-76.

13. Byaruhanga, C., Collins, N.E., Knobel, D., Chaisi, M.E., Vorster, I., Steyn, H.C. and Oosthuizen, M.C. (2016) Molecular investigation of tick-borne hemoparasite infections among transhumant zebu cattle in Karamoja region, Uganda. Vet. Parasitol. Reg. Stud. Rep., 3-4: 24-27.

14. Lorusso, V., Wijnveld, M., Majekodunmi, A.O., Dongkum, C., Fajinmi, A., Dogo, A.G., Thrusfield, M., Mugenyi, A., Vaumourin, E., Igweh, A.C., Jongejan, F., Welburn, S.C. and Picozzi, K. (2016) Tick-borne pathogens of zoonotic and veterinary importance in Nigerian cattle. Parasit. Vectors, 9: 217.

15. Thorpe, W., Muriuki, H.G., Omore, A., Owango, M.O. and Staal, S. (2000) Development of Smallholder Dairying in Eastern Africa with Particular Reference to Kenya. UZ/RVAU/DIAS/DANIDA-ENRECA Project Review Workshop 10-13 January, Bronte Hotel 10.

16. Nguhiu-Mwangi, J., Aleri, J.W., Mogoa, E.G. and Mbithi, P.M. (2013) Indicators of Poor Welfare in Dairy Cows Within Smallholder Zero-grazing Units in the Periurban Areas of Nairobi, Kenya. Insights from Veterinary Medicine, Rita Payan-Carreira, IntechOpen. p50-88. Available from: https://www.intechopen.com/books/ insights-from-veterinary-medicine/indicators-of-poor-welfare-in-dairy-cows-within-smallholder-zero-grazing-unitsin-the-peri-urban-are. Last accessed on 22-05-2019.

17. Behnke, R. and Muthami, D. (2011) The Contribution of Livestock to the Kenyan Economy. IGAD Livestock Policy Initiative Working Paper, 03-11. p1-62.

18. Mukhebi, A.W., Chamboko, T., Callaghan, C.J.O. and Peter, T.F. (1999) An assessment of the economic impact of heartwater (Cowdria ruminantium infection) and its control in Zimbabwe. Prev. Vet. Med., 39(3): 173-189.

19. Kivaria, F.M. (2006) Estimated direct economic costs associated with tick-borne diseases on cattle in Tanzania. Trop. Anim. Health Prod., 38(4): 291-299.

20. Nguhiu-Mwangi, J., Mbithi, P.M.F., Wabacha, J.K. and Mbuthi, P. (2012) Risk (Predisposing) factors for non-infectious claw disorders in dairy cows under varying zero-grazing systems. In: Perez-Marin, C.C., editor. A Bird's-Eye View of Veterinary Medicine. IntechOpen, Rijeka, Croatia. p393-422.

21. Muhanguzi, D., Ikwap, K., Picozzi, K. and Waiswa, C. (2010) Molecular characterization of Anaplasma and Ehrlichia species in different cattle breeds and age groups in Mbarara district (Western Uganda). Int. J. Anim. Vet. Adv., 2(3): 76-88.

22. Charan, J. and Biswas, T. (2013) How to calculate sample size for different study designs in medical research? Indian J. Psychol. Med., 35(2): 121.

23. Kasari, T.R., Miller, R.S., James, A.M. and Freier, J.E. (2010) Assessment of change in risk for release of Ehrlichia ruminantium (Heartwater) into the continental United States following discontinuation of the tropical bont tick (Amblyomma variegatum) eradication program on St. Croix, U.S. Virgin Islands. J. Am. Vet. Med. A, 237(5): 520-530.

24. Jin, H., Wei, F., Liu, Q. and Qian, J. (2012) Epidemiology and control of human granulocytic anaplasmosis: A systematic review. Vector Borne Zoonotic Dis., 12(4): 269-274.

25. Teshale, S., Geysen, D., Ameni, G., Asfaw, Y. and Berkvens, D. (2015) Improved molecular detection of Ehrlichia and Anaplasma species applied to Amblyomma ticks collected from cattle and sheep in Ethiopia. Tick Tick Borne Dis., 6(1): 1-7.

26. Semu, S.M., Peter, T.F., Mukwedeya, D., Barbet, A.F. and Jongejan, F. (2001) Antibody responses to MAP 1B and other Cowdria ruminantium antigens are down-regulated in cattle challenged with tick-transmitted heartwater. Clin. Diagn. Lab. Immunol., 8(2): 388-396.

27. Matos, C.A., Gonçalves, R.L., Ramos, A.I.D., Mendes, S.N., Zanatto, C.D.S. and André, M.R. (2019) Acta tropica 
molecular detection and characterization of Ehrlichia ruminantium from cattle in Mozambique. Acta Trop., 191: 198-203.

28. Kelly, P.J., Lucas, H., Yowell, C., Beati, L., Dame, J., UrdazRodriguez, J. and Mahan, S. (2011) Ehrlichia ruminantium in Amblyomma variegatum and domestic ruminants in the Caribbean. J.Med. Entomol., 48(2): 485-488.

29. Swai, E.S., Mtui, P.F., Chang'a, A.K. and Machange, G.E. (2008) The prevalence of serum antibodies to Ehrlichia ruminantium infection in ranch cattle in Tanzania: A cross-sectional study. J. S. Afr. Vet. Assoc., 79(2): 71-75.

30. Mdladla, K., Dzomba, E.F. and Muchadeyi, F.C. (2016) Seroprevalence of Ehrlichia ruminantium antibodies and its associated risk factors in indigenous goats of South Africa. Prev. Vet. Med., 125: 99-105.

31. Dunning Hotopp, J.C., Lin, M., Madupu, R., Crabtree, J., Angiuoli, S.V., Eisen, J.A., Seshadri, R., Ren, Q., Wu, M., Utterback, T.R., Smith, S., Lewis, M., Khouri, H., Zhang, C., Niu, H., Lin, Q., Ohashi, N., Zhi, N., Nelson, W., Brinkac, L.M., Dodson, R.J., Rosovitz, M.J., Sundaram, J., Daugherty, S.C., Davidsen, T., Durkin, A.S., Gwinn, M., Haft, D.H., Selengut, J.D., Sullivan, S.A., Zafar, N., Zhou, L., Benahmed, F., Forberger, H., Halpin, R.,
Mulligan, S., Robinson, J., White, O., Rikihisa, Y. and Tettelin, H. (2006) Comparative genomics of emerging human ehrlichiosis agents. PLoS Genet., 2(2): e21.

32. Sivakumar, T., Suraj, P.T., Yasotha, A. and Phukon, J. (2017) Identification of suitable housing system for dairy cattle in North-East zone of Tamil Nadu, India, with respect to microclimate. Vet. World, 10(1): 1-5.

33. DeShazer, J.A, Hahn, G.L. and Hongwei, X. (2013) Basic principles of the thermal environment and livestock energetics. In: Livestock Energetics and Thermal Environment Management. Ch. 1. American Society of Agricultural and Biological Engineers, St. Joseph, MI. 1-22.

34. Peter, T.F., Burridge, M.J. and Mahan, S.M. (2002) Ehrlichia ruminantium infection (heartwater) in wild animals. Trends Parasitol., 18(5): 214-218.

35. Tola, A., Kaba, A., Hailu, M., Asefa, Z. and Melesse, K. (2016) Role of female and male headed households in dairy production, processing and marketing in Walmera district of central high lands of Ethiopia. J. Biol. Agric. Healthc., 6(23): 48-61.

36. Louw, M., Allsopp, M.T. and Meyer, E.C. (2005) Ehrlichia ruminantium: An emerging human pathogen? Ann. N. Y. Acad. Sci., 1063(12): 358-360. 